\title{
PENGARUH MOTIVASI DAN STRES KERJA TERHADAP KINERJA DENGAN KETERLIBATAN KERJA SEBAGAI VARIABEL INTERVENING ( STUDI PADA KARYAWAN BAGIAN PRODUKSI ) PT. FITRAFOOD INTERNATIONAL
}

\section{OLEH}

\section{Darrylia Jennyfer Darwin 041141008}

\begin{abstract}
ABSTRAK
Tujuan dari penelitian ini adalah untuk mengetahui adanya pengaruh motivasi dan stress kerja terhadap kinerja dengan keterlibatan kerja sebagai variable intervening (studi pada karyawan bagian produksi) PT. Fitra Food International yang berjumlah 102 orang. Metode pengumpulan data yang digunakan dalam penelitian ini membaca literature- literature dan penelitian sebelumnya dan penyebaran kuesioner. Data yang dianalisis dari hasil tersebut diolah dengan path analisis. Pengujian validitas dilakukan dengan bantuan SPSS 16.0 for windows dan model pengukuran yang diperoleh dari pengolahan data menggunakan AMOS yang menunjukkan hasil penelitian menunjukkan bahwa variable motivasi kerja berpengaruh signifikan terhadap keterlibatan kerja, kemudian variable stress kerja berpengaruh signifikan terhadap keterlibatan kerja, lalu variable keterlibatan kerja berpengaruh signifikan terhadap kinerja karyawan, kemudian variable motivasi kerja berpengaruh signifikan terhadap kinerja karyawan dan variable stress kerja berpengaruh signifikan kinerja karyawan.
\end{abstract}

Kata kunci: motivasi, stress kerja, kinerja, keterlibatan kerja 


\section{Latar Belakang Masalah}

Era globalisasi seperti saat ini, dimana dunia semakin menyatu, tidak bisa lagi kejadian di suatu negara tertutup bagi dunia luar. Teknologi informasi dan komunikasi telah merangsang perubahan hubungan antar bangsa yang tidak bisa lagi dibatasi dengan tembok tapal batas suatu negara. Kondisi tersebut menuntut suatu organisasi atau perusahaan untuk senantiasa melakukan berbagai inovasi guna mengantisipasi adanya persaingan yang semakin ketat. Demikian juga di perusahaan dituntut untuk mempunyai keunggulan bersaing baik dalam hal kualitas produk, servis, biaya maupun sumber daya manusia (SDM) yang profesional.

Keberhasilan manajemen sumber daya manusia tidak lepas dari perilaku individu yang terlibat dalam organisasi tersebut. Perilaku individu dalam organisasi banyak di bahas dalam perilaku organisasi. Namun dalam pengelolaan sumber daya manusia, pembahasan perilaku individu tidak banyak dilakukan atau dipraktekkan. Salah satu perilaku individu yang berkaitan dengan kinerja adalah adanya stress dalam bekerja.

Donnelly (1985:204) menyatakan Job Stres atau stres kerja adalah suatu tanggapan adaptif, ditengahi oleh perbedaan individu dan atau proses psikologi dari setiap kegiatan (lingkungan), situasi, atau kejadian eksternal yang membebani tuntutan psikologis atau fisik yang berlebihan terhadap seseorang. Stres yang berdampak positif dapat menjadi sesuatu yang menyenangkan karena dapat memberikan semacam rangsangan dan motivasi untuk memecahkan suatu masalah sehingga dapat mencapai hasil yang optimal. Adapun stres yang berdampak merugikan misalnya terganggunya kesehatan, kehidupan, penampilan, tingkah laku, dan sikap. Reaksi yang diberikan seseorang dalam menghadapi stressor menunjukkan karakter yang dimilikinya dan sampai dimana batas kemampuan mereka untuk mengatasinya. Sejauh mana tingkat stres dan bagaimana pengaruhnya terhadap kinerja karyawan tentunya akan berbeda tergantung penyikapan masing-masing. 
Mangkunegara (2009:61) motivasi merupakan kondisi atau energi yang menggerakkan diri karyawan yang terarah atau tertuju untuk mencapai tujuan organisasi perusahaan. Motivasi menurut M. Manulang (2001:165) adalah daya perangsang atau daya pendorong, yang merangsang atau mendorong pegawai untuk mau bekerja dengan segiatgiatnya berbeda antara pegawai yang satu dengan yang lainnya. Maksud perbedaan disini adalah disebabkan perbedaan motif, tujuan dan kebutuhan dari masing-masing pegawai untuk bekerja, juga oleh karena perbedaan waktu dan tempat.

Keterlibatan kerja atau Job Involvement adalah internaliasasi nilai-nilai mengenai kebaikan sebuah pekerjaan atau pentingnya sebuah pekerjaan dalam diri seseorang, dan kemungkinan mengukur sejauh mana seseorang dapat bersosialisasi dengan sebuah organisasi. Keterlibatan kerja juga di definisikan sebagai tingkat dimana kinerja seseorang memengaruhi harga dirinya.

Kinerja atau Job Performance merupakan suatu hasil yang dicapai oleh pekerja dalam pekerjaannya menurut kriteria tertentu yang berlaku untuk suatu pekerjaan. Kinerja adalah hasil dari usaha seseorang yang dicapai dengan adanya kemampuan dan perbuatan dalam situasi tertentu. Jadi bisa dikatakan Kinerja merupakan hasil keterkaitan antara usaha, kemampuan dan persepsi tugas. Usaha merupakan hasil motivasi yang menunjukan jumlah energi (fisik atau mental) yang digunakan oleh individu dalam menjalankan suatu tugas. Sedangkan kemampuan merupakan karakteristik individu yang digunakan dalam menjalankan suatu pekerjaan. Kemampuan biasanya tidak dapat dipengaruhi secara langsung dalam jangka pendek. Selanjutnya persepsi tugas merupakan petunjuk dimana individu percaya bahwa mereka dapat mewujudkan usaha-usaha mereka dalam pekerjaan.

Pencapaian yang baik tentunya menghasilkan prestasi. Demikian pula di dunia perusahaan. Karyawan sebagai sumber daya dan modal usaha seharusnya memberikan 
kinerja baik dengan hasil akhir berupa prestasi baik. Ini demi peningkatan kualitas perusahaan termasuk segi pelayanan.

Salah satu contohnya adalah di perusahaan PT. Fitrafood International. Penulis ingin melakukan penelitian pada perusahaan ini dikarenakan adanya long shift pada bagian staf produksinya yang menimbulkan dampak stress terhadap karyawan tersebut serta sejauh mana motivasi mereka dan keterlibatan kerja mempengaruhi kinerja karyawannya. PT. Fitrafood International adalah perusahaan importir dan distributor produk makanan frozen. Capaian kinerja yang selama ini baik, tentunya akan berakibat pada semakin tingginya target capaian pada tahun berikutnya. Ini tentunya bisa menimbulkan adanya stres, gesekan, atau pun keterlibatan kerja yang berpengaruh terhadap optimalisasi para pekrjanya.

\section{LITERATUR DAN HIPOTESIS}

\section{Motivasi}

Robbins (2006) mengemukakan bahwa motivasi adalah keinginan untuk melakukan sebagai kesediaan untuk mengeluarkan tingkat upaya yang tinggi untuk tujuan-tujuan organisasi, yang dikondisikan oleh kemampuan upaya itu untuk memenuhi suatu kebutuhan individual.

Patchen (dalam Srivastava, 2005) menyatakan bahwa seseorang yang memiliki keterlibatan kerja yang tinggi akan menunjukkan perasaan solidaritas yang tinggi terhadap perusahaan dan mempunyai motivasi kerja internal yang tinggi. Individu akan memiliki keterlibatan kerja yang rendah jika ia memiliki motivasi kerja yang rendah dan merasa menyesal dengan pekerjaannya. Artinya, individu yang memiliki keterlibatan kerja yang rendah adalah individu yang memandang pekerjaan sebagai bagian yang tidak penting dalam hidupnya, memiliki rasa kurang bangga terhadap perusahaan, dan kurang berpartisipasi dan kurang puas dengan pekerjaannya. 
Berdasarkan dari definisi di atas maka dapat disimpulkan bahwa keterlibatan kerja merupakan komitmen seorang karyawan terhadap pekerjaannya yang ditandai dengan karyawan memiliki kepedulian yang tinggi terhadap pekerjaan, adanya perasaan terikat secara psikologis terhadap pekerjaan yang ia lakukan, dan keyakinan yang kuat terhadap kemampuannya dalam menyelesaikan pekerjaan.

Oleh karena itu dalam penelitian ini diajukan hipotesis pertama adalah sebagai berikut H1: Motivasi kerja berpengaruh positif dan signifikan terhadap keterlibatan kerja karyawan.

\section{Stres Kerja}

Stres merupakan kondisi ketegangan yang berpengaruh terhadap emosi, jalan pikiran, dan kondisi fisik seseorang. Stres yang tidak bisa di atasi dengan baik biasanya berakibat pada ketikmampuan orang beriteraksu secara positif dengan lingkungannya, baik dalam lingkungan pekerjaan maupun lingkungan luarnya (Siagian, 2008:300).

Kreitner dan Kinicki (2005) mendefinisikan stres sebagai respon adaptif dihubungkan oleh karaktersitik dan atau proses psikologis individu, yang merupakan suatu konsekuensi dari setiap tindakan eksternal, situasi, atau peristiwa yang menempatkan tuntutan psikologis/fisik khusus pada seseorang. Stres kerja tidak dapat dihindari, namun dapat dikurangi dan dikelola. Stres kerja apabila dikelola dengan baik dapat menjadi pendorong dan meningkatkan intensitas kerja, sedangkan apabila tidak dikelola dengan baik stres kerja akan menimbulkan permasalahan yang berdampak negatif bagi individu dan perusahaan. Kreitner dan Kinicki (2005) membedakan antara eustress yakni stres yang positif atau stres yang menghasilkan suatu hasil yang positif dan distress yakni kekuatan destruktif atau stres negatif yang sering menimbulkan masalah fisik maupun mental.

Karyawan dapat menanggapi kondisi-kondisi tekanan tersebut secara positif maupun negatif. Stres dikatakan positif dan merupakan suatu peluang bila stress tersebut merangsang 
mereka untuk meningkatkan usahanya untuk memperoleh hasil yang maksimal. Stres dikatakan negatif bila stres memberikan hasil yang menurun pada produktifitas karyawan. Akibatnya, ada konsekuensi yang konstruktif maupun destruktif bagi badan usaha maupun karyawan. Pengaruh dari konsekuensi tersebut adalah penurunan ataupun peningkatan usaha dalam jangka waktu pendek maupun berlangsung dalam jangka waktu lama.

Oleh karena itu dalam penelitian ini diajukan hipotesis kedua adalah sebagai berikut : H2: Stres kerja berpengaruh positif dan signifikan terhadap keterlibatan kerja karyawan.

\section{Keterlibatan Kerja (Job Involvement)}

Keterlibatan kerja (Job Involvement) disimpulkan oleh Saleh dan Hosek (1976) dalam Yekti (2006) sebagai tingkat sejauh mana seseorang mengidentifikasikan dirinya dengan pekerjaan, berpartisipasi aktif dalam bekerja dan menganggap performansi kerjanya penting bagi harga dirinya. Seseorang yang terlibat dengan pekerjaan akan menganggap pekerjaan memiliki peran penting dalam hidupnya, merasakan bahwa kebutuhan kemandirian dan kontrol terhadap pekerjaan terpenuhi serta merasa harga dirinya meningkat seiring dengan peningkatan kinerja (Kanungo, 1979, dalam Yekti, 2006).

Menurut Kanungo, dalam Liou and Bazemore (1994) Keterlibatan kerja (job involvement) didefinisikan sebagai identifikasi psikologis individual terhadap tugas tertentu. Lawler \& Hall , dalam Nouri (1994) mendefinisikan Keterlibatan kerja sebagai tingkatan dimana seseorang memandang seberapa penting pekerjaannya.

Zagenczyk dan Murrell (2009) meneliti tentang hubungan antara pemberi saran, penerima saran dan sikap kerja karyawan, menemukan bahwa pemberi saran dan penerima saran mempunyai hubungan positif dengan keterlibatan kerja dan keterlibatan pekerjaan ini memiliki pengaruh positif terhadap Kinerja (kinerja) dan dapat dianggap sebagai refleksi pengalaman kerja itu sendiri. 
Dan menurut Cohen (1999) menyatakan bahwa staf / karyawan yang dengan tingkat Keterlibatan kerja yang tinggi, berasal dari pengalaman yang positif di tempat kerja mereka.

Oleh karena itu dalam penelitian ini diajukan hipotesis ketiga adalah sebagai berikut :

H3: Keterlibatan kerja berpengaruh positif dan signifikan terhadap kinerja karyawan.

\section{Kinerja}

Heider, dalam As'ad (2003) mengemukakan teori atribusi atau Expectancy Theory bahwa kinerja merupakan hasil interaksi antara motivasi dan ability, yang dirumuskan dengan formula sebagai berikut: P (Performance) merupakan fungsi M (Motivation) dan A (Ability) yang dapat ditulis sebagai rumus: $\mathrm{P}=\mathrm{f}(\mathrm{M}$ x $\mathrm{A})$. Konsep di atas juga didukung oleh Maier (1965), Lawler dan Porter (1967), serta Vroom (1964). Berdasarkan teori di atas maka seorang karyawan yang rendah dalam salah satu komponennya maka kinerjanya akan rendah pula. Dengan demikian dapat pula diartikan bahwa karyawan yang kinerjanya rendah, maka hal tersebut dapat merupakan hasil dari motivasinya yang rendah atau kemampuannya yang kurang atau kedua-duanya yaitu motivasi dan kemampuannya yang rendah.

Motivasi seseorang berawal dari kebutuhan, keinginan dan dorongan untuk bertindak demi tercapainya kebutuhan atau tujuan. Motivasi merupakan variabel penting, yang dimana motivasi perlu mendapat perhatian yang besar pula bagi organisasi dalam peningkatan kinerja pegawainya.

Higgins (Umar, 2000: 259) berpendapat bahwa terdapat hubungan langsung antara stres kerja dan kinerja karyawan, sejumlah besar penelitian telah menyelidiki pengaruh stres kerja dengan kinerja disajikan dalam model stres-kinerja (hubungan U terbalik) yakni hukum Yerkes Podson (Mas'ud, 2002: 20). Pola U terbalik tesebut menunjukkan pengaruh tingkat stres (rendah - tinggi) dan kinerja (rendah - tinggi). Bila tidak ada stres, tantangan kerja juga tidak ada dan kinerja cenderung menurun. Rangsangan yang terlalu kecil, tuntutan dan 
tantangan yang terlampau sedikit dapat menyebakan kebosanan, frustasi, dan perasaan bahwa kita tidak sedang menggunakan kemampuan - kemampuan kita secara penuh (Looker, 2005: 144).

Oleh karena itu dalam penelitian ini diajukan hipotesis keempat adalah sebagai berikut :

H4 : Motivasi kerja berpengaruh positif dan signifikan terhadap kinerja karyawan.

H5: Stres kerja berpengaruh positif dan signifikan terhadap kinerja karyawan.

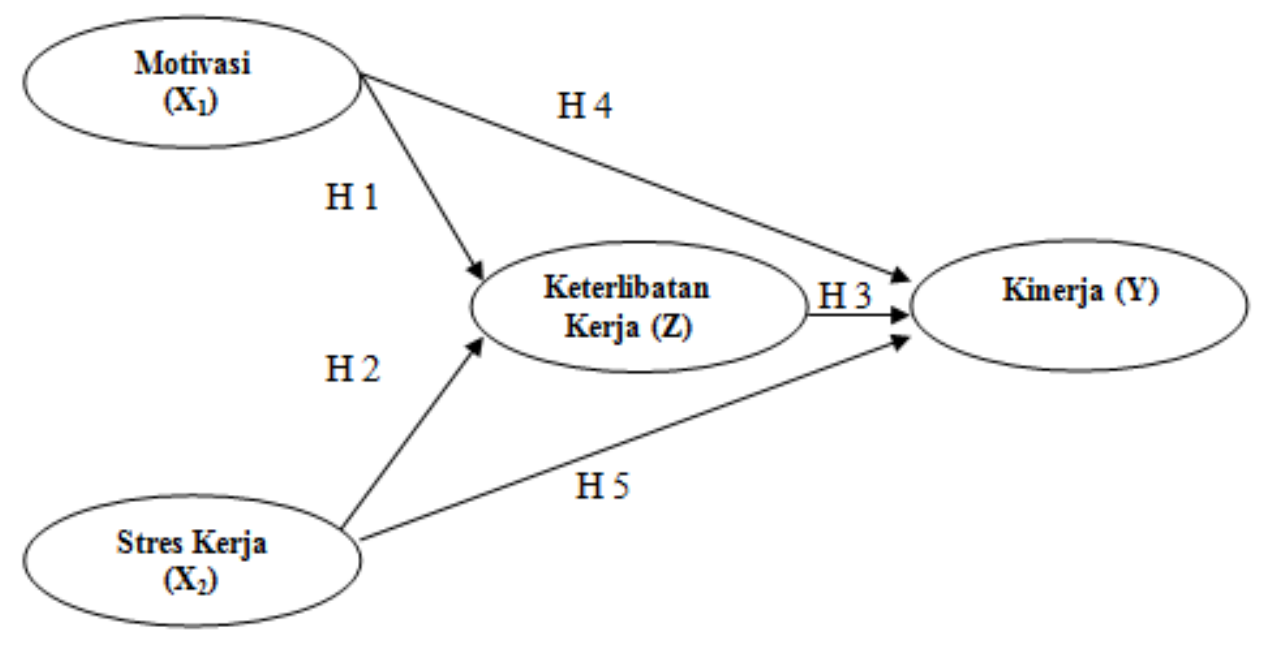

Gambar Kerangka Konseptual Penelitian

\section{METEDOLOGI}

Penelitian ini menggunakan dasar desain penelitian kausal. Berdasarkan dasar desain penelitian yang digunakan maka penelitian ini menggunakan pendekatan kuantitatif. Pendekatan kuantitatif menitikberatkan pada pengujian hipotesis. Jenis dan sumber yang digunakan yaitu data primer yang diperoleh langsung dari penelitian di lapangan dengan mengajukan beberapa pertanyaan yang berkaitan dengan Motivasi, Stres Kerja (Job Stres), Keterlibatan Kerja, dan Kinerja para karyawan serta data sekunder yang diperoleh dari catatan yang telah tersedia di perusahaan. Populasi dalam penelitian ini adalah karyawan bagian produksi PT. Fitrafood International yang berjumlah 102 orang. Uji kualitas data pada 
penelitian ini yaitu reliabilitas, Validitas, Evaluasi atas Outlier

\section{HASIL DAN PEMBAHASAN}

Pengujian ini dilakukan atas butir-butir pernyataan pada kuesioner dengan menggunakan koefisien korelasi pearson dari masing-masing pernyataan dengan skor total yang diperoleh.

Tabel 4.12

Hasil Uji Kecocokan Model Pengukuran

\begin{tabular}{|c|c|c|c|c|}
\hline No & Uji Kecocokan & $\begin{array}{c}\text { Kriteria } \\
\text { Kecocokan }\end{array}$ & Hasil & Keterangan \\
\hline 1 & $\begin{array}{l}\text { Statistik Chi- } \\
\text { Square }\end{array}$ & $\begin{array}{c}\text { Diharapkan kecil, } \\
p \geq 0,05\end{array}$ & $\begin{array}{c}\text { Chi-square }= \\
94,101 \\
\mathrm{p}=0,212\end{array}$ & Good fit \\
\hline 2 & RMSEA & RMSEA $\leq 0,08$ & 0,035 & Good fit \\
\hline 3 & GFI & GFI $\geq 0,90$ & 0,891 & Marginal fit \\
\hline 4 & AGFI & $\mathrm{AGFI} \geq 0,90$ & 0,845 & Marginal fit \\
\hline 5 & CMIN/DF & $\mathrm{CMIN} / \mathrm{DF} \leq 2$ & 1,120 & Good fit \\
\hline 6 & TLI/NNFI & $\mathrm{TLI} \geq 0,90$ & 0,984 & Good fit \\
\hline 7 & CFI & $\mathrm{CFI} \geq 0,90$ & 0,987 & Good fit \\
\hline
\end{tabular}

Sumber: Hasil Pengolahan AMOS 16, diolah.

Statistik Chi-Square digunakan untuk menguji kecocokan antara model dengan sampel dan semakin kecil nilai $\chi^{2}$ maka model semakin baik. Chi-Square $\left(\chi^{2}\right)$ diterima dengan cut off value sekurang-kurangnya $\mathrm{p}>0,05$, mungkin $\mathrm{p}>0,10$ atau $\mathrm{p}>0,20$, yang artinya model semakin baik (Hair, et al., 1998, p.654). Tabel 4.12 menunjukkan nilai chi-square dari hasil uji kecocokan menunjukkan hasil yang baik dimana nilai chi-square adalah 0,212 > 0,05, yang berarti model cocok terhadap sampel yang digunakan.

RMSEA (The Root Mean Square Error Approximation) dapat digunakan untuk mengkompensasi statistik Chi-Square dalam sampel yang besar. Tabel 4.12 menunjukkan nilai RMSEA yang baik dimana nilai RMSEA $0,035 \leq 0,08$. Hal ini berarti tingkat kesalahan model apabila diestimasi dalam populasi tidak terlalu tinggi.

GFI (Goodness of Fit Index) adalah sebuah pengukuran non statistik yang memiliki nilai dari 0 sampai 1 . Tabel 4.12 menunjukkan nilai tersebut berada diantara $0,8 \leq$ GFI $\leq 0,9$ 
sehingga disebut sebagai marginal fit. Hasil ini menunjukkan bahwa model yang diuji dapat memenuhi kriteria yang disyaratkan.

AGFI (Adjusted Goodness of Fit Index) adalah perluasan dari GFI, disesuaikan dengan rasio derajat kebebasan model. Tabel 4.12 menunjukkan nilai AGFI 0,845. Nilai tersebut berada diantara $0,8 \leq \mathrm{GFI} \leq 0,9$ sehingga disebut sebagai marginal fit. Hasil ini menunjukkan bahwa model yang diuji dapat memenuhi kriteria yang disyaratkan.

CMIN/DF adalah statistik chi-square $\left(\chi^{2}\right)$ dibagi DF model sehingga disebut $\chi^{2}$ relatif. Tabel 4.12 menunjukkan nilai CMIN/DF yang baik dimana nilai CMIN/DF adalah $1,120 \leq 2$. Hasil ini menunjukkan bahwa model yang diuji sudah memenuhi kriteria yang disyaratkan.

TLI (Tucker Lewis Index) juga disebut sebagai NNFI (Nonnormed Fit Index). TLI juga dapat digunakan untuk membandingkan sebuah model yang diuji terhadap sebuah baseline model. Tabel 4.12 menunjukkan nilai TLI yang baik dimana nilai TLI adalah 0,984 $\geq 0,90$. Hasil ini menunjukkan bahwa model yang diuji sudah memenuhi kriteria yang disyaratkan.

CFI (Comparative Fit Index) dapat diterima pada nilai yang berada antara 0 dan 1. Tabel 13 menunjukkan nilai CFI yang baik dimana nilai CFI adalah 0,987 $\geq 0,90$. Hasil ini menunjukkan bahwa model yang diuji sudah memenuhi kriteria yang disyaratkan. 


\section{Model Struktural (Structural Model)}

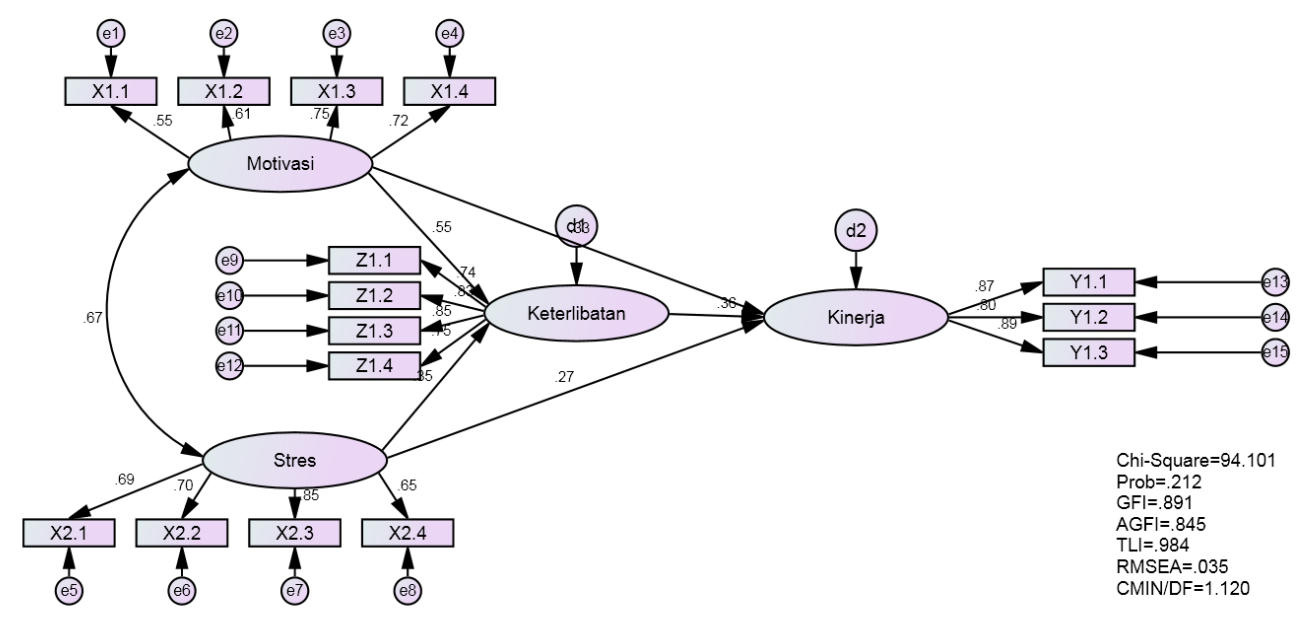

Gambar 2

Structural Model

Model struktural di atas menunjukkan nilai yang marginal karena nilai $p$-value 0,212, nilai RMSEA $=0,035$. Sehingga tidak perlu dilakukan modifikasi terhadap model yang sudah ada.

\section{Pengujian Hipotesis}

Bagian ini berhubungan dengan evaluasi terhadap parameter-parameter yang menunjukkan hubungan kausal atau pengaruh antar satu variabel laten terhadap variabel laten lainnya.

Uji hipotesis dilakukan dengan melihat nilai C.R untuk setiap koefisien. Nilai C.R signifikan apabila $\geq 1,96$ dan $\mathrm{P}<0,05$ yang berarti hipotesis dapat diterima. Apabila, nilai C.R $<1,96$ dan $\mathrm{P}>0,05$ maka tidak signifikan dan hipotesis ditolak. 
Tabel 4.13

Evaluasi terhadap Koefisien Model Struktural dan Kaitannya dengan Hipotesis Penelitian

\begin{tabular}{|l|l|l|c|c|c|c|c|}
\hline & & & Estimate & S.E. & C.R. & P & Keterangan \\
\hline Keterlibatan & $<---$ & Motivasi & .554 & .168 & 3.303 & $* * *$ & Signifikan \\
\hline Keterlibatan & $<---$ & Stres & .318 & .124 & 2.564 & .010 & Signifikan \\
\hline Kinerja & $<---$ & Stres & .383 & .176 & 2.177 & .030 & Signifikan \\
\hline Kinerja & $<---$ & Motivasi & .520 & .258 & 2.017 & .044 & Signifikan \\
\hline Kinerja & $<---$ & Keterlibatan & .561 & .249 & 2.256 & .024 & Signifikan \\
\hline
\end{tabular}

Sumber: Hasil Pengolahan AMOS, diolah.

Besarnya pengaruh antar variabel dilakukan dengan melihat nilai estimate pada setiap jalur. Semakin besar nilai estimate, menunjukkan bahwa pengaruh semakin besar antara variabel yang satu dengan variabel yang lainnya.

1. $\mathrm{H}_{1}$ : "Motivasi kerja berpengaruh signifikan terhadap keterlibatan kerja"

Besarnya nilai CR hitung variabel motivasi kerja terhadap keterlibatan kerja adalah 3,303 dengan tingkat signifikan 0,000. Tingkat signifikan 0,000 menunjukkan bahwa masih dibawah standar level of signifikan yaitu $<0,05$ maka dapat dikatakan bahwa motivasi kerja berpengaruh signifikan terhadap keterlibatan kerja.

2. $\mathrm{H}_{2}$ : "Stres kerja berpengaruh signifikan terhadap keterlibatan kerja"

Besarnya nilai CR hitung variabel stres kerja terhadap keterlibatan kerja adalah 2,564 dengan tingkat signifikan 0,010. Tingkat signifikan 0,010 menunjukkan bahwa masih dibawah standar level of signifikan yaitu $<0,05$ maka dapat dikatakan bahwa stres kerja berpengaruh signifikan terhadap keterlibatan kerja.

3. $\mathrm{H}_{3}$ : "Keterlibatan kerja berpengaruh signifikan terhadap kinerja karyawan"

Besarnya nilai CR hitung variabel keterlibatan kerja terhadap kinerja karyawan adalah 2,256 dengan tingkat signifikan 0,24. Tingkat signifikan 0,024 menunjukkan bahwa 
masih dibawah standar level of signifikan yaitu $<0,05$ maka dapat dikatakan bahwa keterlibatan kerja berpengaruh signifikan terhadap kinerja karyawan.

4. $\mathrm{H}_{4}$ : "Motivasi kerja berpengaruh signifikan terhadap kinerja"

Besarnya nilai CR hitung variabel motivasi kerja terhadap kinerja adalah 2,017 dengan tingkat signifikan 0,044. Tingkat signifikan 0,044 menunjukkan bahwa di bawah standar level signifikan yaitu $\leq 0,05$ maka dapat dikatakan bahwa motivasi kerja berpengaruh signifikan terhadap kinerja.

5. $\mathrm{H}_{5}$ : "Stres kerja berpengaruh signifikan terhadap kinerja"

Besarnya nilai CR hitung variabel stres kerja terhadap keterlibatan kerja adalah 2,177 dengan tingkat signifikan 0,030. Tingkat signifikan 0,030 menunjukkan bahwa di bawah standar level signifikan yaitu $\leq$ 0,05 maka dapat dikatakan bahwa stres kerja berpengaruh signifikan terhadap kinerja.

\section{SIMPULAN DAN SARAN}

\section{Simpulan}

Berdasarkan hasil pengolahan data dengan menggunakan AMOS dapat diambil kesimpulan sebagai berikut :

1. Hasil penelitian menunjukkan bahwa variabel motivasi kerja berpengaruh signifikan terhadap keterlibatan kerja. Terbukti dengan nilai CR sebesar 3,303 dengan tingkat signifikan $0,000<0,05$.

2. Hasil penelitian menunjukkan bahwa variabel stres kerja berpengaruh signifikan terhadap keterlibatan kerja. Terbukti dengan nilai CR sebesar 2,564 dengan tingkat signifikan $0,010<0,05$.

3. Hasil penelitian menunjukkan bahwa variabel keterlibatan kerja berpengaruh signifikan terhadap kinerja karyawan. Terbukti dengan nilai CR sebesar 2,256 dengan tingkat signifikan $0,024<0,05$. 
4. Hasil penelitian menunjukkan bahwa variabel motivasi kerja berpengaruh signifikan terhadap kinerja karyawan. Terbukti dengan nilai CR sebesar 2,017 dengan tingkat signifikan $0,044<0,05$.

5. Hasil penelitian menunjukkan bahwa variabel stres kerja berpengaruh signifikan terhadap kinerja karyawan. Terbukti dengan nilai CR sebesar 2,177 dengan tingkat signifikan $0,030<0,05$.

\section{Saran}

Saran yang dapat diberikan dalam penelitian ini adalah:

1. Perusahaan harus selalu menjaga Motivasi kerja dan Stres kerja yang ada diperusahaan, karena faktor ini merupakan faktor yang berpengaruh terhadap keterlibatan kerja dan kinerja karyawan.

\section{DAFTAR PUSTAKA}

Ashford, S., Lee, C., \& Bobko, P.1989. Content, Causes and Consequences of Job Insecurity: A theory-Based Measure and Substantive Test. Academy of Management Journal, $32,803-829$.

Behaghel, Luc., Moschion, Julie. 2012. “Skilled Labour Supply, IT-Based Technical Change and Job Instability” Institute for the Study of Labor.26 (13), pp.5-27.

Bemhardt, Annette; et all. 1999. "Trends in Job Instability and Wages for Young Adult Men", in Journal of Labor Economics (Chicago, IL), Vol. 17, No. 4 (Oct.), pp. 65-90.

Brooke, P.P., Russell, D.W., \& Price, J.L. 1988. Discriminant Validation of Measures of Job Satisfaction, Job Involvement and Organization Commitment. Journal of Applied Psychology, 73, 139-145. 
Brown, S.P. 1996. Ameta-Analysis and Review of Organizational Research on Job Involvement. Psychological Bulletin, Vol.102, pp.235-55.

Cheloha, R. S., \& Farr, J. L. 1980. Absenteeism, Job Involvement and Job Satisfaction in an Organizational Setting. Journal of Applied Psychology, 65, 467-473.

Cho, Joonmo., Keum, Jaehon. 2004. “ Job Instability in the Korean Labour Market:

Estimating the Effects of the 1997 Financial. International Labour Review, Vol. 143.

Chughtai, A. A. 2008. Impact of Job Involvement on In-Role Performance and Organizational Citizenship Behavior. Journal of Behavioral and Applied Management.

DeFrank, R. S., and J. M. Ivancevich. 1998. "Stress on the Job: An Executive Update”, Academy of Management Executive. 12 (3), pp. 55-67.

De Witte, H., 2005a. “Job Insecurity: Review of the International Literature on Definitions, Prevalence, Antecedents and Consequences", South African Journal of Industrial Psychology, 31(4), pp. 1-6.

Diebold, Francis X.; Neumark, David; Polsky, Daniel. 1997. "Job Stability in the United States", in Journal of Labor Economics (Chicago, IL), Vol. 15, No. 2 (Apr.), pp. 206-235.

Djati, S. Pantja,et.all (2003), Jurnal Manajemen dan Kewirausahaan Vol 5 Maret 2003. UK Petra Surabaya.

Dolke, A.M., \& Srivastara, P.K. (1988). Need Satisfaction, Job Involvement and Intrinsic Motivation: A Factor Analytic study. Indian Journal of Applied Psychology, 25, 1317.

Donnelly, G.I.1985. Organisasi (Perilaku, Struktur, Proses). Erlangga: Jakarta. 
Emery CR, Barker KJ, 2007. "Effect of Commitment, Job Involvement and Teams on Customer Satisfaction and Profit”, Team Performance Manage, 13(3/4), pp. 90-101.

Farber, H., 2010, "Job Loss and the Decline in Job Security in the United States", in Labor in the New Economy, Katharine G. Abraham, James R. Spletzer, and Michael Harper (eds), pp. 223 - 262, University of Chicago Press.

Fathoni, Abdurrahmat. 2006. Organisasi dan Manajemen Sumber Daya Manusia. Jakarta: Rineka Cipta.

Fawzi, I.L. 2001. Stres Kerja Pada Programmer Komputer Di lingkungan Kerja Bank (Jurnal Pengembangan Kualitas SDM dari Perspektif PIO). Jakarta: Psikologi Industri dan Organisasi Fakultas Psikologi UI.

Fisher, R.T., 2001. "Role Stress, the Type A Behavior Pattern, and External Auditor Job Satisfaction and Performance”, Behavioral Research in Accounting, 13, pp. 143-69. Frone, M. R., Russell, C. J., \& Cooper, M. L. (1995). Job Stressors, job Involvement and Employee Health: A Test of Identity Theory. Journal of Occupational and Organizational Psychology, 68, 1 - 11.

Gechman, A. S., \& Wiener, Y. (1975). Job Involvement and Satisfaction as Related to Mental Health and Personal Time Devoted to Work. Journal of Applied Psychology, 60, $521-523$.

Gibson, James L., Ivancevich, Donnelly, Jr, 1995. Organisasi: Perilaku, Struktur, Proses. Edisi I. Bina Rupa Aksara, Jakarta.

Givord, P. and Maurin E., 2004, "Changes in Job Security and their Causes: An Empirical Analysis for France, 1982-2002”, European Economic Review, 48, pp. 595-615.

Gottschalk P. and R. Moffitt, "Changes in Job Instability and Insecurity Using Monthly Survey Data” Journal of Labor Economics, Vol. 17, No. 4, Part 2, pp. S91-S126. 
Greenhalgh , L.and Z. Rosenblatt, 1984. "Job insecurity : toward conceptual clarity", Academy of Management Review, Vol. 9, pp. 438-448.

Green, F., Felstead, A. and Burchell, B., 2000. "Job insecurity and the Difficulty of Regaining Employment: an Empirical Study of Unemployment Expectations”, Oxford Bulletin of Economics and Statistics, 62, pp. 855-883.

Hamalik, Oemar. 1993. Psychologi Manajemen. Tri Gendakarya, Bandung. Hardjana, A.M, 1994. Konflik Di Tempat Kerja, Penerbit Kanisius, Yogyakarta. Hasibuan, S.P. Malayu, 1994. Manajemen Sumber Daya Manusia, Dasar dan Kunci Keberhasilan, CV. Haji Masagung, Jakarta.

Huselid, M. A., \& Day, N. E. (1991). Organizational Commitment, Job Involvement and Turnover: A substantive and Methodological Analysis. Journal of Applied Psychology, 76, 380-391.

Jacobson, D., 1991. “Toward a Theoretical Distinction Between the Stress Components of the Job Insecurity and Job Loss Experiences", Research in the Sociology of Organizations, 9, pp. 1-19.

Jaeger, David A.; Stevens, Ann Huff. 1999. "Is Job Stability in the United States Falling? Reconciling Trends in the Current Population Survey and Panel Study of Income Dynamics", in Journal of Labor Economics (Chicago, IL), Vol. 17, No. 4 (Oct.),pp.1-28.

Johnson, C.D., Messe, L.A. and Crano, W.D., 1984. "Predicting kinerja of lowincome workers: the Work Opinion Questionnaire”, Personnel Psychology, 37, pp. 291199.

Kahn W, 1990). Psychological conditions of personal engagement and disengagement at work", Academy of Manage. J. 33, pp. 692-724. 
Kanungo RN, 1979. "The concepts of alienation and involvement revisited", Psychological Bulletin, 86, pp. 119-138.

Kanungo, R. N. (1982). Measurement of job and work involvement. Journal of Applied Psychology, 67, $341-349$.

Lodahl T, Kejner M, 1965. "The definition and measurement of keterlibatan kerja", Journal of Applied Psychology, 49(1), pp. 24-33.

Mangkunegara, A. Prabu. 2005. Evaluasi Kinerja SDM, Refika Aditama, Bandung.

Mangkunegara, Anwar Prabu. 2009. Manajemen Sumber Daya Manusia: 10 Perusahaan. Bandung: Remaja Rosdakarya.

Manulang, M. 2001. Manajemen Sumber Daya Manusi. Edisi 1. Yogyakarta: BBPE.

Martin TN, \& Hafer JC. (1995). The multiplicative interaction effects of keterlibatan kerja and organizational commitment on the turnover intentions of full- and part-time employees. Journal of Vocational Behavior, 46: 310-331.

Mathis, Robert L dan Jackson, John H. Manajemen Sumber Daya Manusia. Edisi Pertama, Salemba: 2001.

Mauno, S., Kinnunen, U., Mäkikangas, A. and Nätti, J., 2005. "Psychological consequences of fixed-term employment and job insecurity among health care staff', European Journal of Work and Organizational Psychology, 14, pp. 209-237.

Montgomery, D.C., Blodgett, J.G. and Barnes, J.H., 1996, “A model of financial securities sales persons' job stress”, The Journal of Services Marketing, Vol. 10 No. 3, pp. 2134.

Mudrack PE, 2004. "Keterlibatan kerja, obsessive-compulsive personality traits, and workaholic behavioral tendencies". Journal of Organization Change Manage. 17(5), pp. 490-508.

Munandar, Anshar S. Psikologi Industri dan Organisasi. Edisi Pertama. UIP: 2001. 
Probst, T.M., 2002. "The impact of job insecurity on employee work attitudes, job adaptation and, organizational withdrawal behaviors". In Brett, J.M. and Drasgow. F. (eds.), The Psychology of Work: Theoretically Based Empirical Research. Hillsdale, NJ: Lawrence Erlbaum Associates.

Robbins, Stephen. P. 2008. Perilaku Organisasi. PT. Indeks Kelompok Gramedia: Jakarta.

Reisel, W.D., 2002. "Job insecurity revisited: reformulating the affect", Journal of Behavioral and Applied Management, 4(1), pp. 87-91.

Srivastava, S. K. (2005). Organizational Behaviour and Management. New Delhi: Sarup \& Sons.

Sverke, M. and Goslinga, S., 2003. "The consequences of job insecurity for employers and unions: exit, voice and loyalty", Economic and Industrial Democracy, 24(2), pp. $241-270$.

Sverke, M., Hellgren, J., Näswall, K., Chirumbolo, A., De Witte, H. \& Goslinga, S., 2004. Job Insecurity and Union Membership: European Unions in the Wake of Flexible Production. Brussels: P.I.E.-Peter Lang. 